that $\mathrm{Dr}$. Galloway had in mind the fact that my drawings and specimens have been referred to the Morbid Growths Committee. In this is so, Dr. Galloway has departed from estabsished rale in not mentioning my name in connexion with the subjec:. I am aware that two distinguished English pathologists have made an observation previously to mine. Dr. Hadden diagnosed a case as multiple sarcoma which irr. Cobbold declared to be psorospermosis. ${ }^{1}$ Having found muititudes of psorosperms in six consecutive cases of sorcocia. I hare no doubt both opinions were right. Dr. Galloway states that he has not found any record of protozoa laving been found in rodent ulcer. On page 166 of a book which should be familiar to everyone working at the subject $\mathrm{D}$.. Wickham records that he has found psorosperms in one anc. Duorevilh in another case of this clisease. I may conclude $\mathrm{ky}$ saying that I have found psorosperms in the only two cases of rodent ulcer in which I have looked for them. I am, Sirs, yours truly,

J. JACKSON ClaRKE.

St. Margi Hospital Medical School, Feb. 4th, 1893.

\section{SANITATION IN EGYPT}

To the Editors of T'He Laxcer.

StRS, - Yon ailude in a leading article in THE LANCET of Feb. 4th to the shortcomings of England as regards sanitation in Erypt and, if you will allow me to say so, I quice agree with you. There is one point, however, ir yotr indictment which requires amendment. The publishea mortality bills refer to a few towns only, and are fourded on the census of 1882, taken during the Arabi rebellion and utterly untrustworthy. I believe that the nopulation in general is very much understated, and in the rast majority of the towns that is certainly the case. If this view is correct, therefore the death-rate you quote should be proportionately diminished. What is required in Egypt is amelioration of the sanitary condition of the villages from which no returns are published. The rich towns ought to be able to take care of themselves. It is the tax-lader fellah in his wretched mud hut who is the fitting subject for sanitary legislation, and if you will lend your powerîl aid to bring this about you will earn the thanks of several milions of human beings who at present live lives to whicl no English farmer would condemn his cattle.

I am, Sirs, yours truly,

Souttese3, Feh. Ttil, 1893 H. R. GRexise.

\section{A CORRECTION.}

To the Editors of THE LANCET.

SnRs, -I hare just read your interesting leading article on "Myzcedewn," which appears in the current issue of THE LATCET, in which I observe you credit $m e$ with the idea of irjecting thyroid extract. I must not deprive my son of the merit of his discovery, and must therefore ask you to intimate in vour next issue that the idea was conceived by eny son, $\mathrm{Dr}$. George Murray, and not by

Your humble servant,

Northumierland, Feb. 6th, 1883. War. Merr.Y, M.I., sc.

\section{LIVERPOOL.}

(FroM OUR OWN CoRRespondeivt.)

\section{Death of Mr. Nioholas K. Marsh, M.R.C.S.}

Mr. Nicholas KENDRICK MARST, who bad practised in liverpool for forty-five years, died on the 2nd inst., aged sixty-nire his death being of a painfully sudden character. For some years past he had been a member of the City Council and had or the day preceding his death attended the usual monthly neeting, which takes place on the first Wednesday of the morth. He then appeared, according to a local paper, to be in the "pink of health." He never made any complaint that day, and appeared to be as well as usual until afte: breakfast the following morning. He had arranged to attend at the Second Police-court that morning, he having been elected a Justice of the Peace in 1891 and being on the rota. Hearing his bell ring, the servant went in and found him on the floor insensible. His son, Dr. $\mathrm{N}$. Percy Marsh, who lives very near, was soon at hand and found his father dyir., eath taking place soon afterwards. 'The deceased nas a native of Upholland, near Wigan, but came

\footnotetext{
Trandactions of the Pathological Societs, vol. xxxiv., p. 237.
}

to Liverpool when quite young and received part of his medical education at the Liverpool School of Medicine. He had a considerable practice and was much respected by a large circle of friends. Though a strong politician, he was genial and courteous to all his political opponents, and in 1890 he was selected to fill the office of mayor. Acting, however, under the advice of Dr. Glynn, he declined the honour--a decision which was received with much regret by his medical brethren, as the mayoralty in this city had never yet been held by a member of the medical profession. The funeral, which took place on the 6th inst., was attended by a very large number of friends, both professional and lay, amongst whom were the mayor $(\mathrm{Mr}$. R. D. Holt), with some of the city councillors, the clergy and choir of St. Saviour's Church (of which the deceased had been churchwarden), and representatives of the differen essociations and charities with which he had been connected.

The Hospital for Women.

The annual meeting of the subscribers and governors of the Hospital for Women was held on the 6th inst. The report stated that the resources of the institution had been taxed to the utmost extent during the past year, and that if more beds could be provided they would be occupied. But the committee did not feel justified in providing additional beds until there had been some approach to a corresponding increase in their financial resources. The in-patients for the year numbered 513, as against 439 in 1891 . The operations had numbered 261, of which 54 were abdominal sections. The deaths were 14 , of which 11 occurred after abdominal section. There were 3224 out-patients, with 11.326 attendances ; these figures show an increase over those of the previous year. Fortunately, the deficit was not more than $£ 66$, which, it is hoped, will not be increased.

\section{The Oath Question.}

Mr. W. J. Stewart, the stipendiary magistrate, has sent a letter to the three daily papers to correct an erroneous report which had appeared in them-viz., that he was now willing to administer the oath in the Scotch form. He had always been ready to do this since it became the law, and (as mentioned in THE LANCET last week) he had done so for some time past. That anyone who wished to take the oath in that form might do so was a point upon which there conld be no doubt; but there was a difference of opinion as to the meaning of the words "in the form and manner in which an oath is usually administered in Scotland." $\mathrm{He}$ considered that it should be administered by the magistrate and repeated by the witness in the first person for reasons which he gave at great length. The example set by some medical witnesses is being followed by others and by jurors. It is greatly to be hoped that any doubts which may exist as to the proper form of administration will be set at rest by an authoritative decision. The assizes will soon begin all over the country, medical witnesses will most certainly claim to be sworn with uplifted hand before the grand jury in the criminal and in the civil courts, and it is very desirable that there should be no waste of time caused by any doubt as to the proper mode of administering the oath.

Sinall-pox in Liverpool and the Neightourhood.

The amount of intercommunication between Liverpool anc Manchester may be judged from the circumstance that thre different lines of railway run trains hourly through the bus part of the day, which is from an early hour in the morning to a late one in the afternoon. Hence the prevalence o small-pox in Manchester is a matter of anxious interest $t$ the health authorities and the inhabitants of this city. S far the cases of variola have been few, have been promptly reported and as promptly isolated, thus preventing an further spread. There is ample hospital provision for thes cases, and with compulsory notification in force the spread o the disease will, it is hoped, be averted. Persons suffering fron it have shown the most deplorable ignorance in exposin themselves and even in persisting in doing so after repeatec warning. One man suffering from it in a very mild forn presented himself among the out-patients at a hospital Fortunately no harm was done owing to the prompt measure which were taken to prevent this. In the Runcorn distric fifteen persons infected with small-pox were removed to temporary infectious diseases hospital erected on a site pro vided by the Manchester Ship Canal Company. The medica officer of health reported that since the last meeting six fres cases had occurred at Stockton Heath, one at Westo Village and twelve at the Ship Canal huts, Acton Grange ; on patient had died from malignant small-pox.

February 7 th 